\title{
A LEI DE RESPONSABILIDADE FISCAL E A COIBIÇÃO DO DESVIO DE PODER NA EXECUÇÃO ORÇAMENTÁRIA
}

Sérgio Assoni Filho*

\begin{abstract}
Resumo:
O presente artigo aborda o tema do desvio de poder concernente à execução do orçamento público, assim como a possível ligação do desvio de poder com a existência de práticas corruptas no âmbito governamental; apontando para a Lei de Responsabilidade Fiscal como um instrumento voltado ao combate destas patologias de caráter político e econômico.
\end{abstract}

Palavras-chave: Desvio de poder ou de finalidade. Responsabilidade fiscal. Execução orçamentária.

\begin{abstract}
:
This work is about the power shift in relation to enforcement of tax enforcement act, as well as the possible relation between power shift and bribery in government. Tax Responsibility Law is analysed as a mechanism used in repression of these public and economic characters pathologies.
\end{abstract}

Keywords: Shift power or goal. Tax Responsibility. Tax Enforcement.

1. Introdução

Um dos principais problemas a serem enfrentados, no atual estágio de evolução do Estado de Direito, é o da eliminação do arbitrio na atuação dos agentes públicos, que se valem da sua faculdade discricionária, enquanto representantes do Estado-Administração, para alcançarem fins outros que não aqueles atinentes ao legitimo interesse público.

Assim sendo, em diversas ocasiões, os agentes públicos agem encobertos pelo véu da legalidade, justificando como conveniente e oportuna para os administrados a prática de diversos atos que na realidade estão voltados à consecução de finalidades outras, de seus interesses particulares.

Esse desvio de conduta dos agentes públicos, que se utilizam da máquina estatal para a obtenção de vantagens privadas. mediante o uso da competência que lhes foi

Mestre e Doutorando em Direito Fconômico-Financeiro pela Faculdade de Direito da Universidade de São Paulo. 
outorgada pela lei. ficou conhecido na doutrina como desvio de poder ou desvio de finalidace.'

Trataremos do tema de forma mais detalhada, procurando avaliar se a Lei Complementar n. 101, de 05 de maio de 2000, conhecida como a Lei de Responsabilidade Fiscal (I.RF), estabelece, de fato, uma nova postura a ser seguida pelo administrador público, comprometida com os anseios da sociedade e verdadeiramente pública, uma vez que desligada de qualquer interesse particular ou escuso, de modo a contribuir como forma de prevenção desse mal, em particular, no que toca à execução orçamentária, assim como impondo óbices à existência de práticas corruptas no seio do Estado-Administração.

2. Conceito de desvio de poder

Segundo I lauriou, conceitua-se o desvio de poder ou desvio de finalidade da seguinte maneira:

o desvio de poder í o fato de uma autoridade administrativa que, cumprindo um ato de sua compcténcia, observando as formas prescritas, não cometendo nenhuma violaçào formal da lei, usa de seu poder para motivos outros que nâo aqueles em vista dos quais este poder the foi conferido, quer dizer, outros que não a salvaguarda do interesse geral e o bem do serviço. ${ }^{2}$

Também no dizur de outro mestre francês do Direito Público, Laubadère, assim se define a ocorrência do desvio de poder no âmbito da Administração Pública:

há desvio de poder quando uma decisão foi tomada em vista de uma finalidade outra que não aquela para a qual ela deveria ser; a competência foi assim 'desviada' de sua finalidade legitima: 0 ato é ilegal em razão de sua finalidade. ${ }^{3}$

1 A jurisprudência administrativa francesa foi a primeira a utilizar o termo, que é originariamente "détournement de pouvoir" Entre nós há um estudo jurisprudencial a respeito do tema. com um grande valor histórico: VIDAL, Roger. A evolução do desvio de poder na jurisprudência administrativa Revisła de Direito Administrativo, n. 30, p. 34-65, out./cez. 1952.

2 Hauriou. Maurice. Précis de Drou Administratif et de Droit Public. II. ed. Paris: Recueil Sirey. 1927. p. 419.

3 LAUBADĖRE, André de. [et al.]. Manuc' de Droit Admimstratif. 13. ed. Paris: Librairie Générale de Droit et de Jurisprudence. 1988. p. 123-124. 
Para o eminente Seabra Fagundes, ocorre desvio de poder ou desvio de finalidade quando "a lei previu que o ato fosse praticado visando à certa finalidade, mas a autoridade o praticou com finalidade diversa" ${ }^{4}$

Apresentamos ainda o conceito também sintético de Cretella Júnior:

desvio de poder é o uso indevido, que a autoridade administrativa faz, do poder que the é conferido, para atingir finalidade, pública ou privada, diversa daquela que a lei preceituara.

Além disso, o ordenamento jurídico pátrio traz, na Lei da Ação Popular (Lei n. 4.717, de 29 de junho de 1965), em seu art. $2^{\circ}$, "e", o conceito legal de desvio de poder ou desvio de finalidade, nos seguintes termos: "o desvio de finalidade se verifica quando o agente pratica o ato visando a fim diverso daquele previsto, explicita ou implicitamente, na regra da competência"

3. Discricionariedade e arbítrio

Próprio da atuação do Estado-Administração é o exercício da faculdade discricionária, ou seja, o agente público tem uma certa liberdade para a prática dos atos administrativos em nome do interesse público, de acordo com o seu juízo de conveniência e oportunidade.

Isso ocorre em virtude da impossibilidade de o legislador captar e transpor para a lei todas as manifestações do mundo fenomênico concernentes à prática dos atos administrativos, de modo que apenas alguns atos, por ele reputados de maior relevância, terão sua prática regulada pela lei em todos os seus aspectos, enquanto outros, cuja dicção legal oferece alternativas, scrão praticados de acordo com a criteriosa escolha feita pelo administrador público.

Exatamente nesse ponto é que reside a diferença entre um ato administrativo vinculado e um ato administrativo discricionário, pois o administrador pratica o ato vinculado observando estritamente o mandamento legal e sem efetuar qualquer juizo de valor, e já no ato discricionário há espaço para a tomada de uma decisão. conforme o seu julgamento balizado pela sua interação com a realidade social.

Ressaltando, com fulcro na lição de Meirelles, que:

embora não cuidando de todos os aspectos dos atos relegados à faculdade discricionária, o legislador subordina-

- FAGUNDES, Miguel Seabra. O Controle dos IIns Administrativos pelo Poder Judiciário. 2. ed. Rio de Janeiro: José Konfino, 1950. p. 79.

3 CRETELLA JúNIOR, José. Do Desvio de Poder. São Paulo: RT, 1964. p. 27. 
os a um minimo legal, consistente na estrita observância, por parte de quem os vai praticar, da competência, da forma e da finalidade. deixando o mais à livre escolha do agente administrativo (...). Em tal hipótese, executa a lei vinculadamente, quanto aos elementos que ela discrimina, e discricionariamente quanto aos aspectos em que ela admite opçào."

Entretanto, tem se tornado comum entre os administradores públicos o abuso da faculdade discricionária, deixando de haver o respeito àquele mínimo legal antes mencionado, consistente na observância da competência, forma e finalidade discriminadas pela norma juridica, de modo que o ato administrativo discricionário degenera-se em ato arbitrário, ou seja, ilegitimo e inválido, não podendo subsistir.

A distinção entre ato discricionário e ato arbitrário é bem elucidada por Cretella Júnior, que assim se pronuncia:

denomina-se 'discrição' a faculdade concedida ao
funcionário público de agir ou deixar de agir dentro do
âmbito demarcado pela regra juridica, entendendo-se por
'arbitrio" a faculdade de operar sem qualquer limite. em
todos os sentidos. sem a obscrvância de qualquer norma de
direito.'

Ocorre que, disfarçado pela máscara da legalidade do ato administrativo discricionário, o agente público leviano faz uso de sua liberdade de escolha para se afastar do genuíno interesse público, fazendo valer seus interesses pessoais.

Quando a legítima finalidade da lei é preterida pelo administrador, abusando de sua discricionariedade, deparamo-nos então com a figura do desvio de poder ou desvio de finalidade.

O que fica evidenciado na lição de Bonnard:

com efeito, em matéria de finalidade, não há nunca para a Administração um poder discricionário. Pois não the é nunca deixado poder de livre apreciação quanto à finalidade a perseguir. A linalidade $\dot{c}$ sempre imposta pelas leis e regulamentos, seja explicitamente, seja implicitamente. Notadamente, é por isso que com freqüência a finalidade está implicada à natureza do ato, no sentido de que o ato, vista sua natureza, somente pode perseguir uma certa finalidade. ${ }^{\gamma}$

\footnotetext{
Op. cit., p. 104.

Op. cit., p. 40.

BONNARD, Roger. Précis de Droit Administratif. Paris: Recueil Sirey, 1935. p. 228.
} 


\section{Como também enfatiza Gordillo:}

o administrador tem sua competência restrita ao que a lei determina, ou seja, o funcionário tem a faculdade que lhe confere a lei restringida e orientada ao cumprimento de sua finalidade. Em conseqüência, quando o administrador se aparta da finalidade prevista pela lei, sua conduta é por si só antijurídica: o administrador não estava juridicamente autorizado para usar do poder da lei, senão com a finalidade prevista por ela.'

Assim sendo, em última análise, a discricionariedade remete à idéia de uso oportuno da lei, enquanto o desvio de poder remete à idéia de uso indevido da lei. ou no dizer de Franco Sobrinho:

a 'discricionariedade', como faculdade, é aquela permissão que se concede à Administração de agir ou deixar dè agir dentro de um limite estabclecido pela regra jurídica; o 'desvio de poder' como atividade. é aquela ação efetivada longe do espírito da lei. ou melhor. exercitada fora do fim previsto, qualificado. considerado como finalidade própria do ato. ${ }^{10}$

Esse desvio de poder ou desvio de finalidade, como atuação arbitrária do agente público, resulta na nulidade do ato administrativo, uma vez que houve o desvio da finalidade precípua da lei, isto é, desvirtuou-se a consecução da finalidade precisamente eleita pela lei como socialmente relevante e, portanto, de interesse público.

Conforme lição de Tacito:

o desvio de poder é. por definição, um limite à ação discricionária, um freio ao transbordamento da competência legal além de suas fronteiras, de modo a impedir que a prática do ato administrativo, calcada no poder de agir do agente, possa dirigir-se à consecução de um fim de interesse privado, ou mesmo a outro fim público estranho à previsão legal. O batismo do vício de legalidade procura definir, graficamente. a idéia de que a competência discricionária tcm um alvo previsto na lei, do qual a autoridade não se pode desviar sob pena de nulidade do ato (...). A inobservância, pelo agente administrativo, do fim especifico a que a lei endereça o exercicio de sua competência, é causa de

3GORDILlO, Agustin A. El AC1o Administrativo. Buenos Aires: Abeledo Perrot, 1969. p. 286-287.

10 FRANCO SOBRINHO, Manoel de Oliveira. O Controle da Moralidade Administrutiva. São Paulu: Saraiva, 1974. p. 180. 
nulidade do ato administrativo, a ser declarada na própria instância administrativa, ou pela via judicial. ${ }^{11}$

Dessa forma, para que o administrador faça uso de sua faculdade discricionária, a fimm de alcançar o legítimo interesse público, sua ação não pode se ocupar com o mero atendimento da legalidade formal, mas também buscar o cumprimento da lei em sua substância, isto é, visando ao atingimento de seu fïm ou finalidade específica. É o que se pode extrair do ensinamento de Garcia de Enterria:

os poderes administrativos não são abstratos, utilizávcis para qualquer finalidade; são poderes funcionais, outorgados pelo ordenamento em vista de um fim especifico, com o que se apartar do mesmo seca a fonte de sua legitimidade (...). Para que se produza desvio de poder não é necessário que o fim perseguido seja um fim privado. um interesse particular do agente ou autoridade administrativa. mas basta que tal fim, ainda que público, seja distinto do previsto e fixado pela norma que atribua a potestade. ${ }^{12}$

Justamente no atendimento da finalidade específica, isto é, alcançado o fim preciso da lei," é que será evitada, no dizer de Meirelles, "a violação ideológica da lei, ou, por outras palavras, a violação moral da lei" 14

A persecução do interesse público deverá ser pautada pelo atendimento nãosó da legalidade, que é inerente à prática de todo ato administrativo, mas também da moralidade, de modo que o agente público atue com liberdade discricionária sem se

1 TACITO, Caio. Desvio de Poder Legislativo. Revista Trimestral de Direito Priblico, n. 1, p. 62-64. 1993.

12 GARCIA DE ENTERRIA, Eduardo; RAMON FERNANDEZ, Tomas. Curso de Derecho Administrativo. Madrid: Civitas, 1974. v.1, p. 302.

13 Como leciona Régis de Oliveira: "Em suma, quando se concede a alguém a competência para a prática de determinados atos e o agente o pratica objetivando, não o atendimento de interesse público, mas também de um interesse particular, para o qual rão tem competência, ocorrc desvio de poder, já que a norma concede a competência com um fím indicado" (Aıo Administrativo. 3. ed. São Paulo: RT', 1992. p. 96).

Assim se pronuncia ('retella Júnior: "Se a lei previu que o ato deveria ser praticado para atingir determinado fim. mas o agente o praticou com fim diverso, houve a violação da 'intentio legis' contrariou-se o 'animus legis', não interessando, no caso. que a atividade tenha sido licita ou não, porque o ato administrativo será inválido por contrariar o que prescrevera a norma de direito. O fim visado pela autoridade, no exercicio de sua atividade ou atribuição, há de ser o fimm do serviço, fỉm especifico, e não outro, ainda que, possivelmente de interesse público" (Op. cil., p. 35).

Também esse é o parecer de Maria C. S. Vaz Cerquinho: "Desvio de poder é o vicio que enferma o ato administrativo, praticado pelo agente no exercício de uma competència legalmente conferida, a qual é desencaminhada da prossecução da finalidade que the é específica e. para cuja concreção havia sido. precisamente, outorgada pela lei" (O Desvio de Poder no Aro Administrativo. São Paulo: RT, 1979, p. 70). Op. cit. p. 96 . 
desviar do espírito da lei, respeitando a legalidade formal e evitando que o ato administrativo seja, como denominou Alessi. "substancialmente ilegítimo" 15

Então, para que a discricionariedade não se desvirtue em arbítrio. originando a figura do desvio de poder ou desvio de finalidade, o ato administrativo deverá ser restrito no que concerne ao motivo da ação do administrador.

Entretanto, a análise do motivo da ação do administrador não está centrada na sua intenção subjetiva quando da prática do ato, mas nos fatos e circunstâncias que o levaram a praticá-lo, em outras palavras, o motivo do agente público deve ser determinado pela ocorrência dos pressupostos de fato e de direito do ato administrativo, ou seja, além da existência de um dispositivo legal que sirva de fundamento à pratica do ato administrativo. a sua realização deverá ser pautada objetivamente pelas circunstâncias fáticas que conduziram o administrador a tomar uma decisão.

Até mesmo porque, como leciona Cintra:

como qualquer outro ato voluntário, o ato administrativo supõe efetivamente o desenvolvimento de uma atividade psicológica do agente público, que resulta na formação de sua vontade. Representações de fatos, juizos de valor, operações lógicas se sucedem no intimo do agente público. Mas. enquanto em processo, não se revelam no exterior. permanecem fora do plano jurídico. A revelação exterior daquele processo psicológico se dá exatamente através da edição do ato administrativo e de suas circunstâncias, inclusive e notadamente o procedimento administrativo que o precedeu e preparou. No entanto, sua relevância para o direito se limita àquilo em que possa provocar ou denunciar a violação de uma norma juridica incidente na espécie. $\mathrm{km}$ si e por si mesmo. o processo psicológico de formação da vontade do agente público é irrelevante perante o direito (...). Lintendemos, portanto, como motivos do ato administrativo, o conjunto de elementos objetivos de fato e de direito que Ihe constitui o fundamento. Isto significa que, para nós, os motivos do ato administrativo compreendem, de um lado, a situação de fato. que the é anterior, e sobre a qual recai a providência adotada e, de outro lado, o complexo de normas jurídicas por ele aplicadas àquela situação de fato. ${ }^{16}$

Ressaltando que a análise dos motivos da ação eleita pelo agente público como a mais conveniente e oportuna, tendo em vista a consecução da finalidade legal

15 ALESSI, Renato. Intorno ai concetti di causa giuridica, illegittimiri, eccesso di potere. Milano: Giuffri. 1934. p. 90-91.

16 CINTRA. Antônio Carlos de Araújo. Motivo e morivação de ato administrativo. São Paulo: Revista dos Tribunais, 1978. p. 102-105. 
especifica, ultrapassa a noção da legalidade, como bem advertiu Hauriou: "é evidente que a moralidade ultrapassa a legalidade e, conseqüentemente, o desvio de poder ultrapassa em profundidade de ação a violação da lei" 17

Desse modo, também o aspecto moral deverá ser levado em conta quando da averiguação da legitimidade do ato administrativo praticado, isto é, quando da avaliação dos motivos do administrador da coisa pública, uma vez que o exercicio da faculdade discricionária deverá estar em estrita conformidade com a já mencionada finalidade legal específica.

Segundo o entendimento de Franco Sobrinho:

quando o controle se efetiva apurando motivação insuficiente, contraditória ou irracional, o princípio da moralidade passa a influir na tutela da legalidade. O motivo "ilegitimo' interessa à analise dos critérios de boa administração e, portanto, à moralidade administrativa. Não basta que a legalidade seja apreciada stricto sensu, mas sim num sentido mais lato e tomando como importante a conduta regular ou irregular da Administração através da qualificação do ato já materializado. ${ }^{18}$

O problema do desvio de poder está intimamente vinculado à questão da moralidade administrativa, uma vez que o exercício da faculdade discricionária não exime o agente público, a quem foi outorgada legalmente a competência para executar o ato, de atentar para a adequação do motivo à finalidade precípua da lei.

Nesse sentido também se manifesta Queiró, dizendo que:

todos os atos administrativos devem ser praticados pela autoridade competente e sem motivos de moral administrativa reprováveis. Não porque em todos eles haja uma margem de poder discricionário, mas porque todos os atos administrativos devem observar completamente a lei e a moral administrativa . a primeira tal como os tribunais a interpretam, a segunda tal como os tribunais a definem. ${ }^{19}$

A título de conclusão, o agente público competente apenas praticará o ato administrativo sem incorrer em uma arbitrariedade, ou seja, sem a ocorrência do desvio de poder ou desvio de finalidade, se fizer uso de sua faculdade discricionária buscando a consecução da legítima finalidade legal, isto é, o motivo de seu ato pautar-se-á pela

\footnotetext{
Op. cit. p. 420.

8 Op. cit. p. 182-183.

19 QUEIRÓ, Afonso Rodrigues. A Teoria do Desvio de Poder em Direito Administrativo. Revista de Dircilo Administrativo. n. 7, p. 79, jan./mar. 1947.
} 
observância formal da lei e pela moralidade administrativa, sendo esta última representada pela efetivação da escolha que reflita os verdadeiros anseios da sociedade.

\section{A execução orçamentária e a coibição do desvio de poder}

Como já salientado, legítima será a atuação do administrador que fizer uso de sua faculdade discricionária para o atendimento do genuíno interesse público, ou seja, a fim de cumprir a lei não meramente sob o aspecto formal, mas visando ao bem comum.

Evidentemente isso se aplica à execução orçamentária, pois ela somente será sinônima de legalidade e moralidade se for realizada tendo em vista o chamado "espírito da lej", isto é, em nome do atingimento da finalidade especificada na lei como socialmente relevante.

Somente assim o motivo do agente público, ao promover a execução do orçamento público, será qualificado como digno de uma boa e justa administração, em síntese. dotado de moralidade, uma vez que indicará não-só o ficl cumprimento da lei, mas também a existência de um compromisso social e de um adequado planejamento. Sem falar que o agente público não terá sua administração associada a qualquer arbitrariedade ou comportamento indevido, não ocorrendo o desvio de poder ou desvio de finalidade. ${ }^{20}$

A Constituição Federal sinaliza no sentido de que a faculdade discricionária do agente público não pode ser ilimitada com relação aos recursos obtidos, pelo contrário. ele deverá atentar para a observância da lei. Isso fica claro quando ela veda ao administrador, durante a execução orçamentária. a transposição, o remanejamento ou a transferência de recursos de uma categoria de programação para outra ou de um órgão para outro, sem a prévia autorização legislativa (art. 167, VI).

Também a Magna Carta, em seu art. 37, caput, determina estar a Administração Pública submetida ao princípio da moralidade, de forma autônoma em relação aos outros princípios a serem igualmente perseguidos, quais sejam: legalidade, impessoalidade, publicidade e eficiência.

A correta aplicação do princípio da moralidade na Administração Pública vem bem elucidada na lição de Medauar:

20 No dizer de Carlos Borges de Castro: "o ato administrativo mascarado de legalidade pode estar formalmente em ordem, mas materialmente comprometido com a moral, ensejando o controle jurisdicional (...) favorecer ou prejudicar deliberadamente alguém, com fulcro na lci, não constitui, rigorosamente, ralta legal. Revela, porém, comportamento incompativel com o fin legal, um procedimento transgressor que denota desrespeito ao interesse público que the cumpre tutelar. Em última instância, um típico caso de desvio de finalidade" $(O$ Desvio de Finalidade nas Licitações. ذão Paulo: FDUSP - Tese de Doutorado. 1993. p. 20). 
o principio da moralidade administrativa sobressai seja nas situações de desvio de poder, seja nas situações de má fé governamental. seja nos casos em que a decisão destoa do conjunto de preceitos informadores da ação administrativa e destoa do que seria o adequado numa determinada circunstância. A Constituição deixa muito claro que o governante não deve usar o poder de modo desvirtuado, para fins subjetivos; não deve atuar com má fé; não deve desperdiçar ou desviar recursos públicos: deve aplicar a lei de acordo com os reais objetivos desta; deve sempre atuar para atender ao inturesse público, inclusive ao enviar projetos de lei ao Legislativo. ${ }^{21}$

Ainda a este respeito, a Constituição Federal, em seu art. $5^{\circ}$, inciso LXXIII. estabelece que qualquer cidadão poderá propor ação popular tendo em vista a anulação de ato lesivo à moralidade administrativa.

Para corroborar com a existência de uma atuação engajada, refletora de uma atmosfera de legalidade substancial, em que fica claro que o agente público "só pode querer o que a lei purmit' que queira", 22 acreditamos contribuir a lei complementar $\mathrm{n}$. 101, de 05 de maio de 2000, a Lei de Responsabilidade Fiscal (LRF), a partir do momento que integra o ordenamento jurídico pátrio exigindo do administrador uma conduta diferenciada, alastada da prática de qualquer arbitrariedade e marcada pela lisura de seus atos. $^{23}$

Mais precisamente no que se refere ao cumprimento do disposto nas leis orçamentárias, o legislador procurou impedir o abuso da faculdade discricionária do agente público, pois, segundo a inteligência da LRF, em scu art. $8^{\circ} \S$ único, os recursos constantus de uma dotação orçamentária somente poderão ser empregados na consecução do estrito objeto da vinculação legal, ainda que em outro exercício financeiro, ${ }^{24}$ isto é, deverá ser respeitada a finalidade específica da lei orçamentária. ${ }^{25}$

Assim sendo, com a vigência da LRF. a sociedade passou a ter mais um importante instrumento em mãos para policiar o exercício da faculdade discricionária dos agentes públicos, uma vez que licou facilitada a identificação de um motivo ilegítimo na

MEDAuAR, Odete. Desvio de Poder. Revista de Direito Administrativo, n. 228, p. 341, abr. jun. 2002.

Cf. CAETANO, Marcello. Manual de Direito Administrativo. 10. ed. Lisboa. 1973. p. 483.

23 Isso pode ser atestado já no art. I" da LRF, em seu $\S 1^{\circ}$, pois as normas de finanças públicas estabelecidas na lei, tendo em vista uma gestão fiscal dita responsávil, pressupōem: planejamento, transparência, prevençàn de riscos, correção de desvios, cumprimento de metas e observância de limites e condiçôcs.

24 Assim é a disposição da LRF. no § único. do art. $8^{\circ}$ : "Os recursos legalmente vinculados a finalidade especifica serão utilizados exclusivamente para atender ao objeto de sua vinculação, ainda que em cxercicio diverso daquele em que ocorrer o ingresso"

25 Sobre a observância da finalidade especifica da lei na execução orçamentária, vide os seguintes $A$ córdãos do Tribunal de Contas da Uniāo (TCU): n. 119/2002-Plenário. n. 2366,2003-1³ Câmara è n. 252/2003-Plenȧio. 
execução orçamentária, ou seja, a existência de um ato administrativo distanciado do aspecto moral, embora reputado legal do ponto de vista meramente formal. ${ }^{26}$

$\mathrm{O}$ atendimento ao mencionado dispositivo legal busca prevenir a existência dc uma execução orçamentária irregular e, via de conseqüência, a ocorrência do desvio de poder ou desvio de finalidade, pois impossibilita, por exemplo, que uma operação de crédito contratada, visando ao atendimento de uma finalidade legal específica, tenha us recursos dela provenientes utilizados, posteriormente, em uma finalidade diversa.

A utilidade de tal dispositivo da LRF é incontestável, uma vez que a jurisprudência é rica em exemplos de abuso discricionário governamental, pois os agentes públicos muitas vezes fazem uso dos recursos públicos e de seus rendimentos sem atentarem para a finalidade especifica da lei, ${ }^{27}$ assim como os empregam indevidamente em investimentos no mercado financeiro, ${ }^{28}$ ou mesmo os destinam a outros benefícios à comunidade, que não estão relacionados com a finalidade especificada pela lei, ainda que de interesse público. ${ }^{29}$

Em nosso entendimento, ao dispor que os recursos constantes das dotações somente atenderão às finalidades precipuas das leis orçamentárias, a LRF foi providencial na oposição ao desvio de poder ou desvio de finalidade, excrcendo uma espécie de controle prévio, de uma importância ímpar na tentativa de expurgar o arbítrio governamental.

Assim se pronuncia Franco Sobrinho, sobre a necessidade de um controle prévio na prevenção da ocorrência do desvio de poder ou desvio de finalidade:

de todos os sistemas, no entanto, o mais bem adequado à realidade constitucional, à legalidade e à moralidade. é o da fiscalização impeditiva. É o que o controle prévio tem por fim: neutralizar qualquer tentativa capaz de gerar fraude ou abuso de ato praticado. e passivel de anulação (...). Apesar de todos os defeitos, o controle prévio é um dos processos mais eficientes de limitação de facilidades negociáveis: uma condição evidente de contenção de certas prerrogativas

26 Como leciona Marcelo Fortes Barbosa: "O desvio de poder é o uso indevido que o agente faz do poder para atingir fim diverso do que a lei the confere. Em conseqüencia. o elemento prepondcrantc é a moral e a ausência de moralidade traz como pressuposto a ilegitimidade, ainda que, possivelmente. não traga a ilegalidade, eis que ilegitimidade é sinônimo de não moralidade em face da conduta da Administração" (Desvio de Poder. Revista da Faculdade de Direiro FMU. Ano 7. n. 7. p. 77. nov. 1993). A respeito do desvio de finalidade na aplicaçào de recursos públicos e de seus rendimentos, veja os julgados do TCU: Decisões n. 833/2002-Plenário e n. 1286/2002-Plenário; e Acórdãos n. 157/2003-2ª Câmara e n. 767/2003-Plenário.

Sobre o desvio de finalidade na aplicação de recursos públicos no mercado financeiro. vide os seguintes Acórdãos do TCU: n. 59/2002-2 Câmara, n1. 200/2002-1 1 Câmara e n. 248/2002-1ª Càmara.

29 No que toca aos benefícios à comunidade não especificados pela finalidade legal, veja os seguintes Acórdãos do TCU: n. 140/2002-Plenário e 235/2002-Iª Câmara. 
governamentais. de cujos perigos os regimes se mostram demasiadamente sofridos. ${ }^{30}$

O mencionado controle prévio manifesta-se justamente por tentar coibir, preventivamente, a ocorrência de práticas governamentais indevidas, principalmente naqueles momentos em que o agente público se vale das lacunas legais para "preenchêlas" no plano político, atuando arbitrariamente, isto é, abusando de sua faculdade discricionária.

Um dos momentus que se apresentam temerários, ou seja, propensos a tais abusos é o do chamadu ciclo orçamentário, pois as verbas orçamentárias muitas vezes servem como verdadeiras moedas de troca no âmbito governamental. e a aplicação dos dispositivos da L.RF pode vir a scr um importante instrumento para obstar tal prática.

No dizer de Ciraef:

a luta pelo saneamento das finanças públicas culminou com a Lei de Rusponsabilidade Fiscal, que contém medidas permanentes contra o uso impróprio de recursos públicos. A prioridade dada a esse objetivo teve o benéfico efeito colateral de tirar de circulação, em grande quantidade, uma das duas moedas utilizadas como instrumentos clássicos de barganha fisiológica nas relações entre o Governo e setores do Congresso: as verbas orçamentárias solicitadas por politicos que não su destinavam a realizações de inequivoco interesse de seus elcitores, mas a conveniências do próprio politico ou de terceiros. ${ }^{31}$

No que concerne à ocorrência de abusos dos agentes públicos relativos aos orçamentos, também assim se manifesta Schilling: "o ciclo orçamentário é descrito como um momento chave das trocas de favores politicos por beneficios econômicos, como um momento chave da corrupção" 32

Pode-se notar a existência de uma íntima relação entre o desvio de poder ou desvio de finalidade e a corrupção no âmbito govemamental, uma vez que, não raro, o abuso discricionário na tomada de uma decisão do agente público é motivada pelo interesse em uma retribuição material, ${ }^{3:}$ do invés da consecução da finalidade especificada na lei como de interesse público.

30 Op. cit., p. 230-235.

31 GRAEFF, Eduardo. Combate à corrup̧ão e denuncismo na era FHC. Brasilia: Instituto Teotônio Vilela. 2002. p. $11-12$.

32 SCHILLING. Flávia. Corrup̧ão: ilegalidade intolerável? São Paulo: IBC' 'rim, 1999. p. 269.

33 Este é o parecer de Manoel Gonçalves Ferreira liilho: "A corrupçàn que sc há de combater na democracia : aquela que envolve retribuição material. Esta. sim, perverte as instituições e seus mecanismos. $\dot{E}$ a que tem de ser reprimida, é a que deve ser prevenida. Outras práticas poderão ser a-éticas, nào configuram comupçào. Estender a estas o labéu de corrupção è alargar de tal forma o conceito que este se toma impreciso c inútil. 
O que fica claro no conceito de corrupção proposto por Ferreira Filho:

Num sentido amplo, corrupção se aplica a um tipo não de homem mas de conduta, ou comportamento. Mais precisamente de conduta de autoridade pública. Designa, para aproveitar o conceito de Huntington, o comportamento de autoridades públicas que se desviam das normas aceitas. a fim de servir a interesses particulares (...). Em sentido estrito, o termo sc refere à conduta de autoridade que exerce o poder de modo indevido, em beneficio de interesse privado, em troca de uma retribuição de ordem material. ${ }^{34}$

A correlação entre a corrupção e o desvio de poder ou desvio de finalidade também fica evidente na lição de Caggiano, que assim se manifesta sobre a existência de práticas corruptas no âmbito governamental:

(...) pouco há que se alinhavar, refletindo tal modalidade condutas que, em menor ou maior grau, se apresentam contrárias às boas práticas governamentais, as quais devem perseguir metas de interesse público. Alberga esta categoria situações a envolver servidores públicos atuando $\mathrm{em}$ proveito próprio, de seus amigos ou familiares, ensejando a incidència de figuras penais (crimes funcionais, a improbidade adininistrativa) ou ilicitos administrativos. Nesse escaninho, posiciona-se, por evidente, a atuação dos administradores públicos (agentes politicos), atuação acobertada pela aparência de legalidade; adentra-se nos domínios do desvio de poder, do abuso do poder a conter atos, muitas vezes formalizados por lei, os quais, todavia, estampam a intenção de alcançar interesses estranhos aos fins públicos. ${ }^{35}$

Desse modo, a LRF. ao coibir durante a execução orçamentária o abuso da faculdade discricionária dos agentes públicos, também dificulta a ocorrência da corrupção governamental, isto é, a tomada de decisões políticas distanciadas do chamado espírito da lei, uma vez que. em seu íntimo, visam a uma retribuição material.

O ordenamento jurídico brasileiro não se mostra tolerante no que toca ao combate a tais práticas corruptas, ao invés, existe uma enorme gama de leis, estatutos e códigos balizando as ações dos agentes públicos, exemplificando: o Código Penal (Decreto-Lei n. 2.848/1940); a lei dos crimes contra as finanças públicas (n. I0.028/2000);

Pode servir a objetivos políticos, ou da video democracia, foge a um tratamento objetivo da questão" (Corrupção e Democracia. Revista de Direito Administrativo, n. 226, p. 216, out. dez. 2001.).

34 FERREIRA FILHO, Manoel Gonçalves. A corrupção como Renômeno social e politico. Revista da Indístria, Ano I, n. 2, p. 11, abr./jun. 1992.

35 CAGGIANO. Mônica Herman S. Corrupção e financiamento das campanhas elcitorais. Revista de Direilu Constitucional e Internacional, Ano 10, n. 41, p. 220, out./dez. 2002. 
a lei de licitações e contratos administrativos (n. 8.666/1993); a lei da improbidade administrativa (n. 8.429/1992); as leis dos crimes de responsabilidade (n. 1.079/1950 e Decreto-I.ei n. 201/1967); a lei dos crimes contra a ordem tributária (n. 8.137/1990); o Código Eleitoral (Lei n. 4.737/1965); os códigos de ética dos servidores públicos e dos parlamentares; os estatutos dos servidores públicos.

De forma que, no dizer de Grau e Belluzzo:

o dircito positivo brasileiro não é, formalmente, permissivo, de modo a propiciar a prática da corrupção estatal. Pelo contrário, regulamenta procedimentos administrativos. impõe proibições, define crimes e coloca instrumentos de controle da atuação estatal suficientes para coibir os seus desvios. ${ }^{36}$

Além disso, o Brasil é signatário da Convenção Interamericana Contra a Corrupção (CICC), composta pelos países membros da Organização dos Estados Americanos (OEA), realizada em 29 de março de 1996, e que foi posteriormente aprovada pelo Congresso Nacional, conforme os tramites constitucionais, passando a integrar nosso ordenamento jurídico a partir de 07 de outubro de 2002.

De acordo com o disposto no art. Il da mencionada Convenção, no que toca aos seus propósitos, deve haver a cooperação internacional ${ }^{37}$ dos países que dela participaram, a fim de que haja o combate da corrupção no exercicio das funções públicas ou nos atos especificamente vinculados a tal exercício.

Após uma análise um pouco mais detalhada dos seus dispositivos, podemos dizer que a CICC propõe um modelo de ação que busca prevenir a prática da corrupção, mediante a fixação de normas de conduta, bem como de instruções, estudos. sistemas de controle, órgãos de controle e mecanismos que suscitem a transparência dos atos governamentais e, ao mesmo tempo, incitem a participação popular. tudo conforme preconizado pelo seu art. III.

A CICC objetiva também acabar com a impunidade dos agentes públicos que cometerem atos tipificados como corruptos em scus arts. VI, VIII e IX, ou seja, cla

36 GRAU, Eros Roberto: BELLUZZO, Luiz Gonzaga de Melo. A ('orrupçào no Brasil. Revisıa Brasileira de' Estudos Politicos, v. 80, jan. p. 10, 1995.

37 Sobre a necessidade de cooperação entre os paises para um proficuo combate à corrupção, o que é ressaltado pcla CICC, bem lembra Mônica Nicida Liarcia: "Revela, mais, ter-se reconhecido que a corrupção nâo è mais um fenômeno local, estando, antes, aliada ao crime organizado, especialmente ao tráfico ilícito de entorpecentes, de transcendência internacional, exigindo, por parte dos Estados, uma ação coordenada para combatê-la eficazmente" (Responsubiliclude do 1gente Priblico. São Paulo: FDUSP - Dissertação de Mestrado, 2003, p. 242). 
busca a efetividade das leis, uma vez que a mera existência formal de um aparato legal não se mostrou suficiente à extincão das práticas corruptas. ${ }^{38}$

Em nome dessa efícácia da lei, a C'onvenção estabelece que os Estados signatários deverão agir em conjunto também no plano legal, tipificando como delitos em suas legislações internas aqueles atos por cla descritos como de corrupção, de acordo com a inteligência de seu art. VII, uma vě que a ocorrência de condutas governamentais corruptas provoca um desgaste da ordem jurídica existente. isto é. uma espécie de perda de eficácia do ordem jurídica. ${ }^{39}$

Nesse sentido, visando à efutividade da Lei de Responsabilidade Fiscal (LRF), as condutas do agente público consideradas inadequadas pelo legislador foram tipificadas como crime na Lei n. 10.028, de 19 de outubro de 2000, que ficou conhecida como a lei dos crimes contra as finanças públicas. ${ }^{40}$

Consoante a diç̧ão legal da referida lei dos crimes contra as finanças públicas, o Código Penal (Decreto-Lei n. 2.848//940) passou a ter incluídas, em seu título XI. a tipificação de várias outras condutas delituosas.

A Lei n. 10.028/2000 ainda altera os diplomas legais referentes aos crimes de responsabilidade (Lei n. 1.079/1950 e Decreto-Lei n. 201/1967), de modo que, em ambos, condulas são fixadas como crimes de responsabilidade dos agentes públicos relacionadas ao desvio de poder ou desvio de finalidade.

Dessa forma, pode-se dizer que a Convenção Interamericana Contra a Corrupção vem sendo plenamente observada pelo legislador pátrio, pclo menos no que tange à adoção de medidas legislativas capazes de habilitar a ordem jurídica interna ao eficaz combate à corrupção. buscando impedir desvios ou abusos na execução orçamentária, mediante a tipificação de condutas delituosas, a fim de que, ao menos no aspecto legal, o Brasil possa cooperar no cenário internacional anticorrupção.

A preocupação internacional relacionada à corrupção acarretou o desenvolvimento de inúmeros estudos, dos quais resultaram, por exemplo, índices

38 Até porque, um estudo pormenorizado da comupçào no âmbito governamental em diversos países. realizado por Robert Klitgaard, o levou à conclusão de que o "nivel ótimo de comupção" não í igual a zero, pois a destinação de recursos ao seu combate deve visar àquelas manifestações corruptas mais perniciosas, isto é, que causem males sociais mais efetivos, uma vez que a alocação de recursos para o seu combate traria custos sociais demasiadamente elevados. Vide a obra: KLITGAARD, Robert. A corrupção sob controle. trad. Octavio Alves Velho. Rio de Janeiro: Zahar, 1994.

39 Como leciona KLITGAARD: "a conupção gera externalidades negativas ('males públicos'). Acaba com a confiança, a segurança e o dominio da lei" (Ibid., p. 63).

40 A respeito dos crimes fiscais tipificados pela Lei $n$. 10.028/2000, veja os seguintes julgados do Plenário do Tribunal de Contas da União (TCU): Acórdãos n. 130/2003, n. 317/2003, n. 543/2003, n. 1042/2003. n. 1082/2003, n. 1201/2003, n. 1336/2003, n. 1492/2003 e n. 1811/2003; e Decisões n. 434/2001, n. 492/2001 . n. $676 / 2002$. 
comparativos entre os paises acometidos por práticas corruptas no âmbito governamental. Dentre esses indices, destacaram-se o Índice de Percepções da Corrupção (IPCorr) ${ }^{41}$ e os Indicadores de Governância KKZ. ${ }^{42}$

O IPCorr foi criado por iniciativa da Universidade de Göttingen, a partir da incorporação em um só índice de várias informações concernentes à corrupção, de modo a comparar os paises e efetuar uma espécie de ranking anual entre eles.

Uma organização não-governamental (ONG) chamada Transparência Internacional (TI), dedicada ao combate à corrupção, adotou o IPCorr como forma de mensuração dos níveis de corrupção variáveis de país a país, tornando-o conhecido em todo o mundo ${ }^{43} \mathrm{e}$, ao mesmo tempo, instigando internacionalmente o debate sobre o tema.

Por sua vez, os Indicadores de Governância KKZ, resultaram de estudos feitos por pesquisadores do Banco Internacional de Reconstrução e Desenvolvimento (BIRD). também conhecido como Banco Mundial, e são em número de seis: participação popular/transparência; estabilidade política/ausência de violência: eficácia governamental; estrutura regulatória; eficácia da lei; e controle da corrupção.

Para se ter uma idéia prática da aplicação desses indicadores como parâmetro de combate à corrupção, análises de dados feitas com base ncles indicam que 0 Brasil evoluiria da $88^{\mathrm{a}}$ para a $27^{\mathrm{a}}$ posição no ranking de países menos afetados pela corrupção, caso houvesse uma melhoria correspondente a $50 \%$ de sua eficácia legal. ${ }^{.44}$

O estudo feito pelos pesquisadores do Banco Mundial a respeito da corrupção denota a sua preocupação com o tema, dando claros sinais da importância de seu controle aos países que se valem de seus recursos a fim de desenvolverem projetos de infra-estrutura e programas de cunho social.

Assim sendo, o Banco Mundial, como órgão internacional multilateral que teria por escopo auxiliar os países em desenvolvimento chamados "elegíveis", isto é, potenciais beneficiários de seus recursos, incorporou aos seus programas de crédito a variante corrupção, como elemento chave para a concessão dos empréstimos.

\#. As pesquisas para a elaboração do IPCorr foram coordenadas pelo economista Johann Graf Lambsdorfl.

42 Os indicadores KKY foram assim batizados conforme as iniciais dos nomes de seus criadores: Kaulmann. Kraai e Zoido-Lobatón.

43 A revista The Economist divulgou, tm julho de 200I, um ranking entre os paises com base no IPCorr, do qual despontavam a Finlândia c a Nigéria, respectivamente, como o pais de menor e maior indices de corrupção. O Brasil ficou em uma posição intermediária nesse ranking, ocupando a $46^{*}$ posição (Cf. CAGGIANO, Mônica H. S.. op. cit., p. 218).

t. Tal conclusão, com fulcro nos mencionados indicadores, bem como a metodologia aplicada. constam da seguinte obra: ABRAMO, Cláudio Weber. Relaçòes entre indices de percepção de corrupção c outros indicadores em onze paises da América Latina. In: Os Cusıos da ('orrupção. São Paulo: Konrad Adenauer, 2000. p. 47-62. 
O desenvolvimento desses índices comparativos de níveis de corrupção tem o grande mérito de servir de suporte para guiar os investidores, que fatalmente terão uma postura distinta dependendo da posição do país alvo do investimento no ranking internacional de corrupção, ou seja, os índices auxiliarão na mensuração do risco dos referidos investidores ao dirigirem seu capital para este ou aquele país.

Como salienta Speck, a respeito dos indices que avaliam o risco do investimento, "eles identificam a corrup̧̧ão como um risco relevante, que deve ser levado em conta pelos investidores" 45

No dizer de Marcos F. G. da Silva:

a corrupção representaria uma espécie de custo que reduziria a 'eficácia do investimento. Tudo se passa como se tivéssemos que desperdiçar dinheiro à toa para podermos criar novas riquezas no futuro (...). A corrupção pode onerar o crescimento econômico também devido ao fato de afugentar investimentos novos. por criar instabilidade política. O risco político e institucional é sempre levado em conta pelos investidores internacionais e domésticos. Caso esse risco aumente consideravelmente, projetos de novos investimentos podem ser adiados. ${ }^{46}$

A LRF. em conjunto com a Lei n. 10.028/2000, procura conferir uma maior eficácia legal no combate à corrupção e aos abusos discricionários govemamentais, refletindo uma gestão fiscal com maior planejamento, transparência, prevenção de riscos, correção de desvios, cumprimento de metas e observância de limites e condições.

Em suma, a LRF é profilática ao primar pela execução orçamentária voltada ao lcgítimo interesse público, vinculando as dotações estritamente à consecução da finalidade pública especificada na lei orçamentária, de modo a coibir o desvio de poder ou desvio de finalidade e, em última instância, servindo de óbice à existência de práticas qualificadas como corruptas no âmbito da Administração Pública.

São Paulo, outubro de 2005.

45 SPECK, Bruno Wilhelm. Mensurando a corrupção: um revisão de dados provenientes de pesquisas empiricas. In: Os Custos da Corrupção. São Paulo: Konrad Adenauer, 2000, p. 25.

46 SILVA. Marcos Fernandes Gonçalves da. Corrupção e desempenho econômico. In: Os ( uslos da Corrupção. São Paulo: Konrad Adenauer, 2000. p. 72-73. 


\section{Referências}

ABRAMO, Cláudio Weber. Relações entre indices de percepção de corrupção e outros indicadores em onze países da América Latina. In: Os ('ustos da Corrup̧̧ão. São Paulo: Konrad Adenauer, 2000 .

ALESSI. Renato. Intorno ai concenti di causa giuridica, illegittimità, eccesso di potere. Milano: Giuffrè, 1934.

BARBOSA, Marcelo Fortes. Desvio de Poder. Revista da Faculdade de Direito FMU, Ano 7, n. 7, p. 77. nov. 1993.

BONVARD, Roger. Précis de Droit Administratif. Paris: Recueil Sirey, 1935.

(.AFTANO, Marcello. Mamual de Direito Administrativo. 10. ed. Lisboa, 1973.

CAGGiANO, Mônica Herman S. Corrupção e financiamento das campanhas eleitorais. Revista de Direito Constitucional e Internacional. Ano 10, n. 41. p. 220, out./dez. 2002.

C.ASTRO, Carlos Borges de. O Desvio de Finalidade nas Licitações. São Paulo: FDUSP . Tése de Doutorado, 1993.

CERQuinho, Maria C. S. Vaz. O Desvio de Poder no Ato Administrativo. São Paulo: Revista dos Tribunais, 1979.

CINTRA, Antônio Carlos de Araújo. Motivo e motivação de ato administrativo. São Paulo: Revista dos Tribunais. 1978.

CRETElla JúniOR, José. Do Desvio de Poder. São Paulo: Revista dos Tribunais, 1964.

FAGUNDES, Miguel Seabra. O Controle dos Atos Administrativos pelo Poder Judiciário. 2. ed. Rio de Janciro: José Konfino, 1950.

FERREIRA FILHO, Manoel Gonçalves. A corrupção como fenômeno social e político. Revista da Indústria, Ano I, n. 2. p. II. abr./jun. 1992.

FERREIRA FILHO, Manoel Gonçalves. Corrupção e Democracia. Revista de Direito Administrativo, n. 226, p. 216 , out./dez. 2001.

FRA NCO SOBRINHO. Manoel de Oliveira. O Controle da Moralidade Administrativa. São Paulo: Saraiva, 1974.

GARCIA DE ENTERRIA, Eduardo; RAMUN FERNANDEZ. Tomas. Curso de Derecho Administrativo. Madrid: Civitas, 1974, v.1. 
GARCIA, Mônica Nicida. Responsabilidade do Agente Público. São Paulo: FDISSP . Dissertação de Mestrado, 2003.

GORDILlo, Agustin A. El Acto Adiministrativo. Buenos Aires: Abeledo Perrot. 1969.

GRAEFF. Fduardo. ('ombate à corrupção e denuncismo na era FHC. Brasilia: Instituto Teotônio Vilela, 2002.

GRAU, Eros Roberto; BElluZLO, Luiz Gonzaga de Melo. A Corrupção no Brasil. Revista Brasileira de Estudos Politicos, v. 80, jan., p. 10. 1995.

HAURIOU, Maurice. Précis de Droit Administrutif el de Droit Public. II. ed. Paris: Recueil Sirey. 1927.

KLITGAARD, Rubert. A corrupção sob controle. trad. Octavio Alves Velho. Rio de Janciro: Zahar. 1994.

I.AUBADĖRE. André de. [et al.]. Manuel de Droit Administratif. 13. ed. Paris: Librairic Générale de Droil et de Jurisprudence, 1988.

MEDAUAR, Odete. Desvio de Poder. Revista de Direito Administrativo. n. 228, p. 34I, abr./jun. 2002.

OLIVEIRA, Régis de. Ato Administrativo. 3. ed. São Paulo: Revista dos Tribunais, 1992.

QL'ElRó, A fonso Rodrigues. A Teoria do Desvio de Poder em Direito Administrativo. Revista de Direito Administrativo, n. 7. p. 79, jan./mar. 1947.

SCHILLING, Flávia. Corrupção: ilegalidade intolerável? São Paulo: IBCCrim, 1999.

SILVA, Marcos Fernandes Cionçalves da. Corrupção e desempenho econômico. In: $O s$ Custos da Corrup̧̧ão. São Paulo: Konrad Adenauer, 2000.

SPECK, Bruno Wilhelm. Mensurando a corrupção: um revisão de dados provenientes de pesquisas empiricas. In: Os Custos da Corrupçào. São Paulo: Konrad Adenauer, 2000.

TACITO. Caio. Desvio de Poder Legislativo. Revista Trimestral de Direito Público. n. 1, 1993.

VIDAL. Roger. A evolução do desvio de poder na jurisprudência administrativa. Revista de Direito Administrativo, n. 30, p. 34-65, out./dez. 1952. 